\title{
Prognostic factors and overall survival of breast cancer in the city of Goiania, Brazil: a population-based study
}

\section{Fatores prognósticos do câncer de mama e sobrevida global em cinco e dez anos na cidade de Goiânia, Brasil: estudo de base populacional}

Ruffo de Freitas Júnior, tCBC-GO1,2; Rodrigo Disconzi Nunes'; Edesio Martins33; Maria Paula Curado ${ }^{4,5}$; Nilleana Maya Aires Freitas ${ }^{2}$; Leonardo Ribeiro Soares'i; José Carlos Oliveira ${ }^{3}$.

\section{A B S T R A C T}

\begin{abstract}
Objective: to analyze the overall survival and prognostic factors of women with breast cancer in the city of Goiânia. Methods: this is a retrospective, cross-sectional, observational study that included women with malignant neoplasms of the breast identified by the Goiânia Population-based Cancer Registry. The variables studied were age at diagnosis, tumor size, staging, axillary lymph node involvement, tumor grade, disease extent, hormone receptors, and c-erb-B2 oncoprotein. We performed overall survival analyzes of five and ten years. Results: we included 2,273 patients in the study, with an overall survival of $72.1 \%$ in five years and $57.8 \%$ in ten years. In the multivariate analysis adjusted for tumor size, the factors that influenced the prognosis were axillary lymph nodes, histological grade, progesterone receptor, c erb B2, T staging and disease extension. Conclusion: overall survival in ten years is below that observed in other countries, and possibly reflects what happens with the majority of the Brazilian population. The prognostic factors found in this population follow the same international patterns.
\end{abstract}

Keywords: Breast Neoplasms. Epidemiology. Survival. Prognosis.

\section{INTRODUCTION}

B reast cancer is the most frequent malignant neoplasm in the female population, representing a public health problem on a global scale $\mathrm{e}^{1-3}$. For the year 2016, the National Cancer Institute (INCA) estimated 57,960 new cases of breast cancer among Brazilian women, with a gross rate of $56.2 / 100,000$; for the state of Goiás, 1,680 new cases, and gross rate of 52.09/100,000; and for the city of Goiânia, 250 new cases, and gross rate of $76.07 / 100.000^{4}$. Although the mortality rate has decreased in some European countries $^{5}$, in Brazil it remains stable, representing the main cause of cancer death among Brazilian women ${ }^{6,7}$, as well as in the city of Goiânia6,8.

Survival is the most used parameter to evaluate the results of the diagnosis and treatment of a malignant tumor with observations obtained in health records ${ }^{9-11}$. The age of the patient at diagnosis, tumor size, number of lymph nodes involved, degree of tumor differentiation, molecular subtype and clinical staging are the main parameters used to evaluate survival and play a fundamental role in the therapeutic planning of this neoplasia ${ }^{10-12}$.

Survival studies are important in the evaluation of the distribution of resources and in the identification of the main prognostic factors in a given region and population. However, few data are available on population-based breast cancer survival. This study aimed to evaluate the overall survival of women with breast cancer residing in Goiânia.

\section{METHODS}

This is a retrospective, population-based, overall survival study that included women living in the city

1 - Federal University of Goiás (HC/UFG), Mastology Program, Clinics Hospital, Goiânia, GO, Brazil. 2 - Goiás Association to Cancer Combat (ACCG), Araújo Jorge Hospital, Goiânia, GO, Brazil. 3 - Goiás Association to Cancer Combat (ACCG), Goiânia Population-based Cancer Registry, Goiânia, GO, Brazil. 4 - International Prevention Research Institute (iPRI), Senior Research, Lyon, Auvergne-Rhône-Alpes, France. 5 - AC Camargo Cancer Center, AC Camargo Hospital, São Paulo, SP, Brazil. 
of Goiânia, Goiás state, Brazil, with malignant neoplasms of the breast, with a primary diagnosis from 1995 to 2003.

\section{Goiânia Population-Based Cancer Registry (RCBPGO)}

The RCBPGO, created in 1986, represents one of the most important cancer registries in Brazil and has worked continuously since its creation until the present day ${ }^{13}$. Incident cases are collected from general hospitals, cancer hospitals, specialized clinics and diagnostic centers. Periodically, the service coordinator evaluates these sources, taking into account the provision of complete data or the difficulty of attending ${ }^{13}$. For case inclusion criteria, the registry classifies and codes cases according to ICD-O (International Classification of Diseases for Oncology) and the recommendations of the International Association of Cancer Registries. Confirmation of the diagnosis by histopathological examination in $90 \%$ of cases is enough to guarantee the quality of data and information generated by a Population-Based Cancer Registry ${ }^{13}$. In the period from 1989 to 2003, the confirmation of the diagnoses performed by this means in the RCBPGO was $94.7 \%^{14}$.

\section{Study population}

We selected the sample through the RCBPGO database, including all the cases of breast cancer in the period from January 1, 1995 to December 31, 2003. We excluded the cases of in situ breast cancer in the same period. For the analysis of survival, the time of follow-up or of the active search for the women had a cut-off date of December 31, 2010.

\section{Data collection}

We modified the questionnaire used to collect the variables based on a previous study carried out by Abreu et al. ${ }^{10}$, in 2002, in the population of Goiânia, for the period 1988 to 1990 . We obtained additional information on each case in hospital records and in the archives of pathological anatomy laboratories. To identify the vital status of the patients in the analyzed period, we collected data from the Goiás Mortality Information System (SIM), the TELELISTA system (www. telelistas.net), to obtain the current telephone number or addresses of relatives and/or neighbors, and the Regional Electoral Court of Goiás (TRE-GO) for cases that attended or not the 2008 elections.

\section{Study variables}

We considered the following variables for the study: age at diagnosis (0-49 years, 50-59 and over 60); tumor size in centimeters $(2 \mathrm{~cm}$, greater than $2 \mathrm{~cm}$ and less than $5 \mathrm{~cm}$ and greater than $5 \mathrm{~cm}$ ); clinical staging, according to the TNM system of the American Joint Committee of Cancers (AJCC); axillary lymph nodes (uncommitted, one to three committed, four to nine committed and more than ten committed); histological grade, according to the classification of Bloom and Richardson (1957), grade I being the most differentiated tumors, grade II, the moderately differentiated, and grade III, the anaplastic (G1, G2 and G3, respectively); disease extent (localized, regionalized and metastasis); estrogen (ER) and progesterone (PR) receptor by immunohistochemical reaction, being considered positive or negative, as reported by each laboratory tending to consider the positivity when there was more than $1 \%$ of cells marked in the tumor invasion area; presence of c-erb-B2 oncoprotein, classified from zero to three crosses, only those reported as three crosses being considered positive.

\section{Data analysis}

We divided overall survival into groups of five and ten years of follow-up. We counted time from the date of diagnosis to the occurrence of the event of interest (death) or until censorship (loss due to observation time when the participant completed the previously stipulated follow-up period without dying). Women who remained alive until the end of the follow-up date (maximum follow-up time of 60 or 120 months) were considered as censored in the study. After completing the variables collection and active search of the women, we used the SPSS ${ }^{\circ}$ for Windows version 18.0 software to construct the database and to compute the Kaplan-Meier method of survival and the log rank test, with a 95\% confidence interval. For the multivariate analysis, we used the Cox regression model, in which we adjusted the variables for tumor size. 


\section{Ethical aspects}

The present study was approved by the Ethics in Research Committee of the Araújo Jorge Hospital of the Goiás Association to Cancer Combat (ACCG). All recommendations of good clinical practice were followed according to resolution CNS 466/2012 and the Helsinki Convention.

\section{RESULTS}

We included 2,273 women residing in Goiâ- nia, with a confirmed diagnosis of malignant neoplasm of the breast between the period of 1995 and 2003. We obtained access to medical records of 1,579 (69.4\%) of them, with adequate collection of the variables. In 694 (30.5\%) cases, the medical records were not available (Table 1). At the time of diagnosis of breast cancer, 616 $(53.8 \%)$ women had a tumor between $2 \mathrm{~cm}$ and $5 \mathrm{~cm}$, 595 (52.9\%) had no axillary lymph node involvement, and the predominant histological grade was $\mathrm{G} 2$, with $841(70.6 \%)$ cases. In table 1 shows the complete distribution of variables by included women.

Table 1. Distribution of the study variables by the included women $(n=2,273)$.

\begin{tabular}{lcc}
\hline Variable & Cases & $\%$ \\
\hline Age at diagnosis & & 42.4 \\
$0-49$ & 963 & 26.8 \\
$50-59$ & 609 & 30.8 \\
$>60$ & 699 & 100.0 \\
\hline
\end{tabular}

Tumor size

$=2 \mathrm{~cm}$

$>2=5 \mathrm{~cm}$

$>5 \mathrm{~cm}$

Total with information *

Histological Grade

G1

G2

G3

Total with information *

Lymph Nodes Committed

None

1 to 3

240

4 to 9

160

14.2

10 or more

131

11.6

Total with information *

1126

100.0

Estrogen receptor

Positive 505

Negative

Total with information * 
Progesterone receptor

Positive

441

60.0

Negative

294

40.0

Total with information *

735

100.0

c-erb-B2

Positive

88

Negative

637

87.9

Total with information *

725

100.0

\section{Staging - $T$}

T1

215

21.9

$\mathrm{T} 2$

441

45.1

T3

140

14.3

T4

183

18.7

Total with information *

979

100.0

\section{Staging $-\mathrm{N}$}

NO

588

57.5

N1

322

31.4

N2

113

11.1

Total with information *

1023

100.0

Disease extent

Localized

Regional

622

31.8

Metastasis

166

8.4

Total with information *

1960

100.0

*Total of patients with information for this particular variable.

Overall survival at five years was $72.1 \%$, and for women with tumors smaller than $2 \mathrm{~cm}, 85.5 \%$. For women who presented G1 tumors, survival was $87.6 \%$, and for women without axillary lymph node involvement, $90.2 \%$. As for estrogen, progesterone and c-erb-B2 oncoprotein receptors, the highest five-year survival rates were ER positive $(83.0 \%)$, PR positive (84.9\%) and c-erb-B2 negative (79.6\%). With regard to staging, the best prognoses were for women with T1 (90.8\%) and N0 (86.0\%). As for disease extent, wo- men with tumors with localized disease and confined to the breast had a five-year overall survival of $84.1 \%$.

Overall survival in ten years, on its turn, was $57.8 \%$. In patients with tumors smaller than $2 \mathrm{~cm}$ the survival was $68.5 \%$, being $62.5 \%$ among those with tumors of 2 to $5 \mathrm{~cm}$. Patients with lymph node involvement had survival at ten years of $58 \%$, while for those with free axilla, it was $77 \%(p<0.001)$. We observed the same in patients with G1 tumors (80.2\%) and $\mathrm{G} 3$ tumors (55.1\%). Women with positive estro- 
gen $(64.5 \%)$ and progesterone $(66.6 \%)$ receptors had better prognoses, as well as those with c-erb-B2 negative tumors (63.7\%). Patients with tumors detected in the early stages had the highest overall survival rates at ten years.

In the univariate analysis of the five-year overall survival, the following variables were significant: age at diagnosis $(p<0.002)$; tumor size $(p<0.001)$, histological grade $(p<0.001)$; number of committed lymph nodes $(p<0.001)$; ER $(p<0.001) ; P R(p<0.001)$; T staging $(p<0.001)$; $N$ staging $(p<0.001)$; and the presence of metastatic disease $(p<0.001)$. The c-erb-B2 variable was not significant $(p<0.06)$. In the univariate analysis of the ten-year overall survival, similar values were found in all variables except ER $(p<0.005), c$-erb-B2 $(p=0.005)$ and age at diagnosis $(p<0.001)$.

In the five-year multivariate analysis adjusted for tumor size, the cumulative risk of death from breast cancer was higher among women with histological grade G3, with lymph node involvement, negative PR, more advanced staging (T3 / T4) and metastatic disease (Table 2). For the ten-year analysis, in addition to the factors found in the five-year one, the c-erb-B2 variable was also significant (Table 3).

Table 2. Multivariate analysis of overall survival in 60 months (five years) of women with breast cancer in the city of Goiânia (1995-2003).

\begin{tabular}{|c|c|c|}
\hline Study variables & $\mathrm{HR}(95 \% \mathrm{Cl})$ & $p$ value \\
\hline Histological grade & & 0.004 \\
\hline $\mathrm{G} 1 / \mathrm{G} 2$ & 1.00 & \\
\hline G3 & $2.39(1.31-4.33)$ & \\
\hline Committed lymph nodes & & 0.002 \\
\hline No & 1.00 & \\
\hline Yes & $2.73(1.43-5.20)$ & \\
\hline Estrogen receptor & & 0.64 \\
\hline Positive & 1.00 & \\
\hline Negative & $1.15(0.62-2.13)$ & \\
\hline Progesterone receptor & & 0.01 \\
\hline Positive & 1.00 & \\
\hline Negative & $2.27(1.21-4.24)$ & \\
\hline c-erb-B2 & & 0.30 \\
\hline Negative & 1.00 & \\
\hline Positive & $1.38(0.74-2.57)$ & \\
\hline T Staging & & $<0.001$ \\
\hline $\mathrm{T} 1 / \mathrm{T} 2$ & 1.00 & \\
\hline $\mathrm{T} 3 / \mathrm{T} 4$ & $2.79(1.63-4.75)$ & \\
\hline Disease extent & & 0.014 \\
\hline Localized/Regional & 1.00 & \\
\hline Metastasis & $2.78(1.23-6.31)$ & \\
\hline
\end{tabular}

* Adjusted by the size of the tumor; HR: Hazard Ratios. 
Table 3. Multivariate analysis of overall survival in 120 months (ten years) of women with breast cancer in the city of Goiânia (1995-2003).

\begin{tabular}{|c|c|c|}
\hline Study variables & $\mathrm{HR}(95 \% \mathrm{Cl})$ & $p$ value \\
\hline Histological grade & & 0.008 \\
\hline $\mathrm{G} 1 / \mathrm{G} 2$ & 1.00 & \\
\hline G3 & $2.01(1.20-3.40)$ & \\
\hline Committed lymph nodes & & 0.004 \\
\hline No & 1.00 & \\
\hline Yes & $2.18(1.28-3.68)$ & \\
\hline Estrogen receptor & & 0.24 \\
\hline Positive & 1.00 & \\
\hline Negative & $1.36(0.80-2.30)$ & \\
\hline Progesterone receptor & & 0.02 \\
\hline Positive & 1.00 & \\
\hline Negative & $1.81(-3.011 .09)$ & \\
\hline c-erb-B2 & & 0.034 \\
\hline Negative & 1.00 & \\
\hline Positive & $1.73(1.04-2.87)$ & \\
\hline T Staging & & $<0.001$ \\
\hline $\mathrm{T} 1 / \mathrm{T} 2$ & 1.00 & \\
\hline $\mathrm{T} 3 / \mathrm{T} 4$ & $2.48(1.59-3.85)$ & \\
\hline Disease extent & & 0.036 \\
\hline Localized/Regional & 1.00 & \\
\hline Metastasis & $2.24(1.05-4.76)$ & \\
\hline
\end{tabular}

* Adjusted by the size of the tumor; HR: Hazard Ratios.

\section{DISCUSSION}

The epidemiological data on breast cancer in Goiânia6,8,14, as well as the variation in incidence in recent years ${ }^{15}$, have been described periodically. However, few survival studies were performed using data from population-based registries. In this scenario, stands out the RCBPGO, whose data were the source of three previous survival studies that included women between 1988 and 199010, 1990-19949 and 19952003 (present series). Despite the methodological differences, we observed an increase in survival from one series to the other, corresponding to $57 \%, 65.4 \%$ and $72.1 \%$, respectively. This increase was possibly related to improvements in local screening and diagnosis of breast cancer ${ }^{16-18}$, which led to a reduction in advanced cases and an increase in initial cases ${ }^{14,19}$. The inclusion of new targeted drugs and therapies should also have contributed to this outcome improvement ${ }^{20,21}$.

Recently the CONCORD-2 study was published, which evaluated more than 25,000,000 people diagnosed with malignant neoplasms between 1995 and 2009, followed in 279 population-based registries from 67 countries. In South and Central America, breast cancer survival rates increased between 1995-1999 and 2005-2009, mainly in Brazil, from $78 \%$ to $87 \%^{3}$. We should note that the difference in variation between the five-year survival found in the CONCORD-2 analysis (87.0\%) and that found in the present study $(72.1 \%)$ is justified because these are different outco- 
mes. The CONCORD-2 study evaluated net survival, in which the outcome for survival analysis is only death related to breast cancer, with deaths related to other causes considered as censorship ${ }^{3}$. We evaluated overall survival, for which all patient deaths were considered as outcome. Thus, the difference found relates to the methodological question and not to information divergence ${ }^{22}$.

Other studies conducted in Brazil, using data from hospital-based cancer registries, also found overall survival at five years similar to the present one, including the Barretos Cancer Hospital series (74.8\%) and the Santa Catarina Breast Cancer Research Group $(76.2 \%)^{23,24}$. On the other hand, a study conducted by the Brazilian Breast Cancer Research Group (GBE(AM), using different hospital-based records, showed that overall survival was influenced by the type of health insurance, with patients in the public system presenting lower survival $(p<0.001)$ compared with the patients in the private system. In the subgroup evaluation, there was no difference between patients with clinical stage $0-I I(p=0.176)$, but patients with stage III-IV in the public health system had significantly lower overall survival compared with the private system subgroup $(p=0.008)$. These data reinforce the importance of clinical staging to the diagnosis of breast cancer, whose early detection may minimize the differences in survival observed between the public and the private care systems.

Regarding the overall survival in ten years in Brazil, only the study by Abreu et al. ${ }^{10}$ evaluated information collected in population-based registries, showing a general survival of $41.5 \%$ between 1998 and 2000 in the city of Goiânia. In the present series, overall survival after ten years of follow-up was $57.8 \%$, which maintains the pattern of increase in overall survival rates in the city of Goiânia. However, it still differs considerably from other studies, which showed a relative survival rate of $86.0 \%$ in Sweden and $85.7 \%$ in Finland ${ }^{1,26}$, possibly due to the absence of adequate mammographic screening in the Brazilian population.

In Europe, the ONCOPOOL study evaluated 16,944 women treated at ten reference centers for breast cancer between 1990 and 1999. Overall survi- val at ten years was $80 \%$. In this study, we highlight the difference in survival between the patients who received the diagnosis through screening programs (84\%) and those diagnosed on physical examination $(76 \%)^{1}$. The divergences found between the European study and this series are possibly due to the absence of a population screening program for breast cancer and inadequate mammography coverage in Brazil18,19. These data reinforce the current recommendations of the Brazilian Mastology Society, which warrants the screening of breast cancer from age 40 onwards ${ }^{27}$.

In the five-year multivariate analysis, adjusted for tumor size, factors influencing the prognosis were axillary lymph nodes, histological grade, progesterone receptor expression, T staging, and disease extent (Table 2). These data are in agreement with other hospital-based studies that evaluated women with breast cancer at reference centers for the diagnosis and treatment of breast cancer $12,23,24$.

The c-erb-B2 variable was only significant in the ten-year multivariate analysis (Table 3). The high number of "no information" for this variable (Table 2) may have impaired the results in the five-year evaluation. The first immunohistochemistry analyzes only began to be performed at the Araújo Jorge Hospital (reference center in cancer of the state of Goiás), where most of the patients in the study (51.6\%) were enrolled in March 1996 and were only included in the routine after a few years.

Among the limitations of the current study, we highlight the difficulties of standardization in the filling of charts and records and in the identification of variables. These limitations are inherent to studies based on secondary data ${ }^{24}$, and do not interfere with the credibility and relevance of the studies in question. Still, considering the survival studies after trackable tumors, the possibility of anticipation and duration biases stands out. However, overall survival remains a clinical outcome of practical relevance ${ }^{10}$, which may be associated with other variables of interest and translate a broader evaluation of the strategies aimed at the control of such tumors. The robustness of the present study rests on the number of cases and on the reliability of the follow-up, since the active search on the patients' vital status allowed us to infer high 
quality, with a low possibility of bias in relation to the overall survival outcome. It is possible that the results found should reflect what happens to the majority of the Brazilian population. We should also note that the overall survival in ten years is below that observed in other countries ${ }^{1,26}$ and therefore, that resources related to early diagnosis and treatment should be better provided to the Brazilian population.

\title{
R E S U M O
}

\begin{abstract}
Objetivo: analisar a sobrevida global e os fatores prognósticos de mulheres com câncer de mama na cidade de Goiânia. Métodos: estudo observacional, retrospectivo, transversal, que incluiu mulheres portadoras de neoplasias malignas da mama identificadas pelo Registro de Câncer de Base Populacional de Goiânia. As variáveis estudadas foram: idade ao diagnóstico, tamanho do tumor, estadiamento, comprometimento dos linfonodos axilares, grau tumoral, extensão da doença, receptores hormonais e oncoproteína c-erb-B2. Foram realizadas análises de sobrevida global, de cinco e de dez anos. Resultados: foram incluídas no estudo 2273 pacientes, com sobrevida global em cinco anos de $72,1 \%$ e de $57,8 \%$ em dez anos. Na análise multivariada ajustada pelo tamanho do tumor, os fatores que influenciaram o prognóstico foram: linfonodos axilares, grau histológico, receptor de progesterona, c-erb-B2, estadiamento T e extensão da doença. Conclusão: a sobrevida global em dez anos está abaixo da observada em outros países, e possivelmente reflete o que acontece com a maioria da população brasileira. Os fatores prognósticos encontrados nesta população seguem o mesmo padrão internacional.
\end{abstract}

Descritores: Neoplasias da mama. Epidemiologia. Sobrevida. Prognóstico.

\section{REFERENCES}

1. Blamey RW, Hornmark-Stenstam B, Ball G, BlichertToft M, Cataliotti L, Fourquet A, et al. ONCOPOOL - a European database for 16,944 cases of breast cancer. Eur J Cancer. 2010;46(1):56-71.

2. Gonzaga CM, Freitas-Junior R, Curado MP, Sousa ALL, Souza-Neto JA, Souza MR. Temporal trends in female breast cancer mortality in Brazil and correlations with social inequalities: ecological time-series study. BMC Public Health. 2015;15:96.

3. Allemani C, Weir HK, Carreira $H$, Harewood $R$, Spika D, Wang XS, Bannon F, Ahn JV, Johnson CJ, Bonaventure A, Marcos-Gragera R, Stiller C, Azevedo e Silva G, Chen WQ, Ogunbiyi OJ, Rachet B, Soeberg MJ, You H, Matsuda T, Bielska-Lasota M, Storm H, Tucker TC, Coleman MP; CONCORD Working Group. Global surveillance of cancer survival 1995-2009: analysis of individual data for $25,676,887$ patients from 279 population-based registries in 67 countries (CONCORD-2). Lancet. 2015; 385(9972):977-1010. Erratum in: Lancet. 2015;385(9972):946.

4. Instituto Nacional do Câncer José Alencar Gomes da Silva. Coordenação de Prevenção e Vigilância. Estimativa 2016: incidência de câncer no Brasil [Internet]. Rio de Janeiro: INCA, 2016 [citado em 2016 Jul 09]. Disponível em: http://www.inca.gov.br/ estimativa/2016/estimativa-2016-v11.pdf

5. Malvezzi M, Bertuccio P, Levi F, La Vecchia C, Negri E. European cancer mortality predictions for the year 2014. Ann Oncol. 2014;25(8):1650-6.

6. 6. Freitas-Junior $R$, Gonzaga CMR, Freitas NM, Martins E, Dardes RC. Disparities in female breast cancer mortality rates in Brazil between 1980 and 2009. Clinics (São Paulo). 2012;67(7):731-7.

7. Kluthcovsky AC, Faria TN, Carneiro FH, Strona R. Female breast cancer mortality in Brazil and its regions. Rev Assoc Med Bras (1992). 2014;60(4):387-93.

8. Gonzaga CM, Freitas-Junior R, Souza MR, Curado MP, Freitas NM. Disparities in female breast cancer mortality rates between urban centers and rural areas of Brazil: ecological time-series study. Breast. 2014;23(2):180-7.

9. Coleman MP, Quaresma M, Berrino F, Lutz JM, De Angelis R, Capocaccia R, Baili P, Rachet B, Gatta G, Hakulinen T, Micheli A, Sant M, Weir HK, Elwood JM, Tsukuma H, Koifman S, E Silva GA, Francisci S, Santaquilani M, Verdecchia A, Storm HH, Young JL; CONCORD Working Group. Cancer survival in five continents: a worldwide population-based study (CONCORD). Lancet Oncol. 2008;9(8):730-56.

10. Abreu E, Koifman RJ, Fanqueiro AG, Land MGP, Koifman S. Sobrevida de dez anos de câncer de mama feminino em coorte populacional em Goiânia (GO), Brasil, 19881990. Cad Saúde Colet. 2012;20(3):305-13. 
11. Xing $Y$, Meng $Q$, Sun $L$, Chen $X$, Cai L. Survival analysis of patients with unilateral and bilateral primary breast cancer in Northeast China. Breast Cancer. 2015;22(5):536-43.

12. Balabram D, Turra CM, Gobbi H. Survival of patients with operable breast cancer (Stages I-III) at a Brazilian public hospital--a closer look into cause-specific mortality. BMC Cancer. 2013;13:434.

13. Moura L, Curado MP, Simões EJ, Cezário AC, Urdaneta M. Avaliação do registro de câncer de base populacional do município de Goiânia, estado de Goiás, Brasil. Epidemiol Serv Saúde. 2006;15(4):717.

14. Nunes RD, Martins E, Freitas-Júnior R, Curado MP, Freitas NM, Oliveira JC. Descriptive study of breast cancer cases in Goiânia between 1989 and 2003. Rev Col Bras Cir. 2011;38(4):212-6.

15. Freitas-Junior R, Freitas NMA, Curado MP, Martins $E$, Silva CMB, Rahal RMS, et al. Incidence trend for breast cancer among young women in Goiânia, Brazil. Sao Paulo Med J. 2010;128(2):81-4.

16. Unger-Saldaña K. Challenges to the early diagnosis and treatment of breast cancer in developing countries. World J Clin Oncol. 2014;5(3):465-77.

17. Corrêa RS, Freitas-Junior R, Peixoto JE, Rodrigues DC, Lemos ME, Marins LA, et al. [Estimated mammogram coverage in Goiás State, Brazil]. Cad Saúde Pública. 2011;27(9):1757-67. Portuguese.

18. Freitas-Junior R, Rodrigues DC, Corrêa RD, Peixoto JE, de Oliveira HV, Rahal RM. Contribution of the Unified Health Care System to mammography screening in Brazil, 2013. Radiol Bras. 2016;49(5):305-10.

19. Martins E, Freitas-Junior R, Curado MP, Freitas NM, Oliveira JC, Silva CM. [Temporal evolution of breast cancer stages in a population-based cancer registry in the Brazilian central region]. Rev Bras Ginecol Obstet. 2009;31(5):219-23. Portuguese.

20. Hamy-Petit AS, Belin L, Bonsang-Kitzis $H$, Paquet C, Pierga JY, Lerebours F, et al. Pathological complete response and prognosis after neoadjuvant chemotherapy for HER2-positive breast cancers before and after trastuzumab era: results from a real-life cohort. Br J Cancer. 2016;114(1):44-52.

21. Kümler I, Knoop $A S$, Jessing $C A$, Ejlertsen $B$, Nielsen DL. Review of hormone-based treatments in postmenopausal patients with advanced breast cancer focusing on aromatase inhibitors and fulvestrant. ESMO Open. 2016;1(4):e000062.

22. 22. Freitas-Junior $R$, Soares $L R$, Barrios $C H$. Cancer survival: the CONCORD-2 study. Lancet. 2015;386(9992):428-9.

23. 23. Carneseca EC, Mauad EC, Araujo MA, Dalbó RM, Longatto-Filho A, Vazquez VL. The Hospital de Câncer de Barretos Registry: an analysis of cancer survival at a single institution in Brazil over a 10-year period. BMC Research Notes. 2013;6:141-51.

24. Schneider IJC, d'Orsi E. [Five-year survival and prognostic factors in women with breast cancer in Santa Catarina State, Brazil]. Cad Saúde Pública. 2009; 25(6):1285-96. Portuguese.

25. Liedke PE, Finkelstein DM, Szymonifka J, Barrios CH, Chavarri-Guerra Y, Bines J, et al. Outcomes of breast cancer in Brazil related to health care coverage: a retrospective cohort study. Cancer Epidemiol Biomarkers Prev. 2014;23(1):126-33.

26. De Angelis R, Sant M, Coleman MP, Francisci S, Baili $P$, Pierannunzio D, Trama A, Visser O, Brenner $H$, Ardanaz E, Bielska-Lasota M, Engholm G, Nennecke A, Siesling S, Berrino F, Capocaccia R; EUROCARE-5 Working Group. Cancer survival in Europe 19992007 by country and age: results of EUROCARE 5 - a population-based study. Lancet Oncol. 2014;15(1):23-34.

27. Urban LABD, Peixoto JE, Ferreira CAP, Canella EO, Kefalasb AL, MaranhãoNMA, etal. Recommendations of Colégio Brasileiro de Radiologia e Diagnóstico por Imagem, Sociedade Brasileira de Mastologia, and Federação Brasileira das Associações de Ginecologia e Obstetrícia for imaging screening for breast cancer. Radiol Bras. 2012;45(6):334-9.

Received in: 16/03/2017

Accepted for publication: 11/05/2017

Conflict of interest: none.

Source of funding: none.

\section{Mailing address:}

Ruffo de Freitas Júnior

E-mail: ruffojr@terra.com.br / ribeiroufg@hotmail.com 